Al-Fikra: Jurnal Ilmiah Keislaman, Vol. 4, No. 2, Juli-Desember 2005

\title{
FIKIH KELAUTAN \\ PERSPEKTIF ALQURAN TENTANG PENGELOLAAN POTENSI LAUT
}

\author{
Ahmad Yusam Thobroni
}

\begin{abstract}
As khalifah Allah, human being is authorized to manage such parth of the earth to take the benefit from it. But the sea that is God's grant for human being life has to be preserved for nex generation which also have their righ og this God's grant. Therefore, for the exploration a well-balanced method is needed to avoid the of damage of the sea adn its contents. The sea beside as cheap transportation medium, it also contains much natural resources which can be explored like fishery, mining, mineral, oil and gas, etc. Positioning the exploration of the sea as one of common platform in economic development of Indonesia, it seems a feasible solution for the Indonesians to overcome the crisis.
\end{abstract}

Key words: Fiqh, maritime potency, and al-Qur'ân

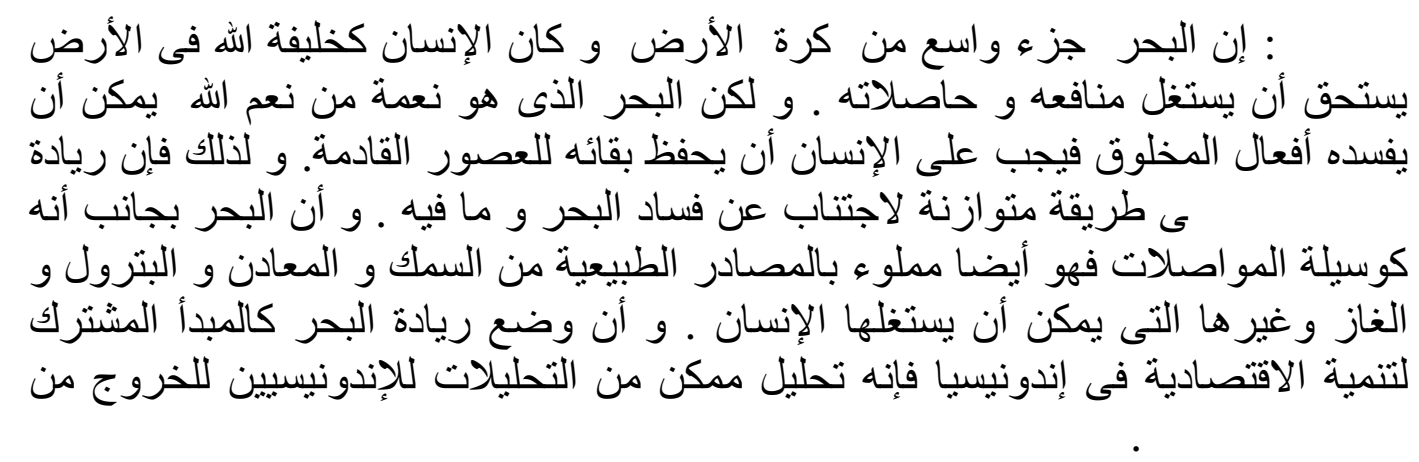

\section{Pendahuluan}

Permasalahan kelautan hampir terlupakan dalam kebijakan pembangunan nasional. Padahal sejarah nasional kita menunjukkan bahwa nenek moyang bangsa Indonesia adalah para pelaut handal yang terkenal keberaniannya dalam mengarungi lautan lepas hanya dengan menggunakan perahu-perahu Pinisi kecil. Betapa hebatnya pelaut-pelaut Bugis (Makassar) menembus ombak dan badai, atau Kerajaan Sriwijaya yang dengan jayanya menguasai perdagangan laut. Lebih dari itu, fakta historis berupa catatan sejarah tentang Sriwijaya, Majapahit, dan kesultanan Islam tumbuh dan mencapai puncak kejayaannya melalui perkembangan ekonomi dan politik di pesisir dan lautan, seperti Tuban, Jepara, Pekalongan, Gresik, Surabaya, Makassar, dan lain-lain. Semboyan "Jalesveva Jayamahe" (berarti; di laut kita jaya) sedikit banyak sebagai cerminan akan kejayaan dan luasnya perairan Indonesia, dengan rakyatnya yang senantiasa menggantungkan mata pencahariannya dari hasil laut. ${ }^{1}$ 
Sayangnya, kejayaan tersebut kini hanya tinggal kenangan. Yang ada sekarang adalah kenyataan bahwa dalam beberapa dekade terakhir ini potensi kelautan tercampakkan. Yang ada hanyalah nelayan-nelayan miskin mengaisngais ikan di lautan dengan jala yang sobek di sana-sini. Sementara kapal-kapal asing-dengan segala kecanggihan teknologi penangkapan dan pengolahan ikan - bebas berseliweran menangguk ikan berton-ton di perairan Nusantara. ${ }^{2}$

Selama ini model kebijakan perekonomian Indonesia berpola kebijakan "Mataram" (mengutamakan pembangunan di darat). Padahal Indonesia merupakan negara yang memiliki wilayah lautan luas, yang menyimpan berbagai macam sumber daya alam. ${ }^{3}$ Tampaknya, untuk mengembalikan kejayaan bangsa Indonesia di laut, sudah saatnya arah pola perekonomian Indonesia diubah dari model kebijakan "Mataram" menjadi model kebijakan negara kelautan "Sriwijaya". Kebijakan ini menyadarkan kita, bahwa betapa asingnya kita selama ini dengan laut, dan sebaliknya betapa bersemangat kita membangun sektor industri teknologi informatika, elektronika, bioteknologi, advanced manufacturing, dan lain-lain, sehingga potensi laut kita terlupakan, seakan-akan laut kita tidak memberikan alternatif sebagai penyumbang devisa bagi negara. ${ }^{4}$

Suatu kenyataan bahwa permukaan planet bumi yang luasnya diperkirakan mencapai 510 juta $\mathrm{km}$ persegi, ternyata hampir $2 / 3$ bagiannya (sekitar $70 \%$ ) terdiri dari wilayah lautan. ${ }^{5}$ Hanya $1 / 3$ bagian saja yang merupakan wilayah daratan. Adapun wilayah laut Indonesia sendiri, terdiri lebih dari 3/4 luas wilayah nasional yang menghubungkan antara satu pulau dengan pulau lainnya. Melihat kondisi wilayah Indonesia yang demikian, maka sudah sewajarnya bila dalam situasi krisis yang dihadapi saat ini, kita mulai kembali membangun kejayaan lewat laut. Laut di samping sebagai sarana transportasi yang murah, juga menyimpan banyak sumber daya alam yang dapat dieksplorasi, antara lain berbagai sumber bahan bangunan seperti pasir, gravel, gelas; sumber mineral seperti manganese, cobalts, lumpur mineral, phosphorites; sumber makanan seperti ikan dan berbagai tanaman laut; sumber bahan-bahan kimia seperti sodium dan potasium; sumber energi dari ombak dan konversi energi panas. Laut pula sebagai sumber minyak bumi yang melimpah ruah dan sebagai sarana rekreasi dan kesehatan. ${ }^{6}$

Khusus sektor perikanan, saat ini, belum dipandang sebagai sumber kekuatan ekonomi nasional. Padahal potensi perikanannya sangat besar. Namun kenyataannya sektor perikanan dan kelautan hanya dianggap sebagai sektor pelengkap atau penunjang pembangunan sektor lain seperti industri dan pertanian. Oleh karena itu, pembangunan nasional sudah saatnya diperluas ke kawasan pesisir, termasuk sektor ekonomi, persoalan sosial, dan perkembangan kebudayaannya. Dengan demikian, banyak sektor yang dapat digali serta dikembangkan di wilayah lautan kita.

Memposisikan eksplorasi laut sebagai salah satu common platform (landasan bersama) dalam pembangunan ekonomi Indonesia, tampaknya, bukan saja sebuah solusi yang mungkin dapat dicapai oleh bangsa Indonesia untuk bangkit 
dari krisis, tetapi juga sebagai koreksi atas kekeliruan kebijaksanaan selama 50 tahun yang Mataram sentris, padahal sosio-geografi Indonesia bukan hanya terdiri dari Pulau Jawa, tetapi terdiri dari beribu pulau dengan laut sebagai penghubungnya. ${ }^{7}$

Berpijak pada pemikiran di atas, penggalian konsep laut dari dalam Alquran perlu dilakukan, agar masyarakat mengetahui bagaimana seharusnya mengelola, mengeksplorasi, dan memanfaatkan laut. Sehingga dengan begitu mereka mendapatkan kesejahteraan dan kebahagiaan dalam kehidupannya. Idealisme Islam menghendaki agar persoalan dikembalikan dan diselesaikan berdasarkan ajaran yang terkandung dalam Alquran dan Sunah. ${ }^{8}$ Dengan begitu, Alquran berfungsi sebagai pedoman bagi hidup dan kehidupan manusia. ${ }^{9}$

Kajian tentang laut telah dilakukan oleh kalangan pakar kelautan. Secara umum kajian tersebut didasarkan pada pendekatan ilmu profan yang sekularistik, yang merupakan derivasi dari realitas rasional yang diabstraksikan ke dalam konsep kelautan. Namun kajian tersebut tidak terkait dengan nilainilai profetis Islam (ris \pm lah Isl \pm miyyah).

Implikasi pengembangan konsep kelautan sekuler di tengah masyarakat Islam dapat mengakibatkan timbulnya standar nilai ganda yang membingungkan. Di satu sisi, konsep kelautan sekuler tidak memberi tempat secara proporsional bagi nilai spiritual Islam, dan di sisi lain, masyarakat Islam mendambakan legitimasi spiritual Islam. Bahkan di bawah naungan ekologi sekular, masyarakat Muslim mendapat intimidasi, baik politis maupun ekonomis, yang digencarkan oleh satu masyarakat dengan dalih berkehidupan kontra ekologis. Padahal sebenarnya hanya luapan sentimen keagamaan, politis, dan ekonomis belaka.10 Dengan demikian, perlu dirumuskan konsep laut dan pengelolaannya yang menjunjung tinggi nilai-nilai spiritual agama.

Selanjutnya, masalah yang diangkat dalam tulisan ini adalah bahwa laut yang merupakan anugerah Allah swt. yang tak ternilai harganya bagi umat manusia-dimana di dalamnya mengandung beragam potensi sumber daya alam laut yang amat kaya - selama ini belum dimanfaatkan dan dikelola secara optimal. Kebijakan pemerintah dalam pembangunan nasional masa lalu yang cenderung kepada pola "Mataram sentris",11 mempengaruhi lambatnya akselerasi pembangunan di sektor kelautan, yang notabene sebagian besar dalam sektor ini terdiri dari masyarakat nelayan. Faktor di atas menyebabkan laut belum dikelola dan dimanfaatkan secara optimal guna menunjang kesejahteraan masyarakat. Masalah ini selanjutnya dicarikan solusi dengan menawarkan konsep laut dan pengelolaannya menurut perspektif Alquran.

Tulisan ini bertujuan untuk membangun sebuah konsep laut dan pengelolaannya menurut Alquran dengan berupaya menggali suatu penafsiran terhadap petunjuk-petunjuk Alquran mengenai laut. Tulisan ini diharapkan dapat membantu usaha-usaha peningkatan penghayatan dan pengamalan ajaran-ajaran serta nilai-nilai Alquran, khususnya berkaitan dengan pengelolaan laut bagi kehidupan manusia. 


\section{Bentuk-bentuk Pengungkapan "Laut" dalam Alquran}

\section{a. Tinjauan Kebahasaan}

Dalam mengungkap masalah "laut", Alquran menggunakan terma $a l-b a ¥ r$ dengan berbagai bentuk derivasinya (kata jadian), yang terulang sebanyak 41 kali. ${ }^{12}$

Kata بح (ba¥r) merupakan kata Arab yang-dalam bahasa Indonesiaberarti "laut". 13 Oleh karena itu, kata $b a ¥ \mathrm{r}$ ini yang akan didasarkan oleh penulis sebagai obyek kajian dalam pembahasan di sini, dengan alasan bahwa terma بحر $(b a ¥ \mathrm{r})$ dan semua bentuk derivasinya menunjuk pada makna "laut". Dari pembahasan kata tersebut diharapkan konsep laut yang Qurani dapat dirumuskan.

Selanjutnya, kata $b a ¥ r$ ditinjau dari segi etimilogi berasal dari kata dasar

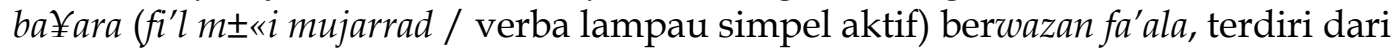
akar huruf-huruf $b \pm^{\prime}-¥ \pm^{\prime}-r \pm^{\prime}{ }^{\prime}{ }^{4} \quad$ Kata $b a ¥ r$ merupakan bentuk majdar (nomina) dari ba¥ara - yab¥aru - ba¥ran. Menurut Ibn F士ris (w. 395 H.), laut dinamakan dengan " $b a ¥ r$ " oleh karena luas dan terhamparnya lautan tersebut.15 Dengan demikian kata ba¥r mempunyai makna etimologis "الإنبساط و السعة" (terhampar dan keluasan).

Secara leksikal, Ibn Man§-r (1223-1311 H.) menyatakan bahwa kata $b a ¥ r$ bermakna air yang banyak, baik asin maupun tawar - sebagai lawan dari kata alnahr (sungai). Laut dinamakan dengan istilah $b a ¥ r$ karena kedalaman dan keluasannya, dan air laut didominasi oleh rasa asin sehingga sedikit kemungkinannya tawar. Dalam pada itu, bila seseorang menyatakan kalimat ك. , maka kata di sini berarti "asin", karena ia berfungsi sebagai sifat dari kata ماء yang terletak sebelumnya-sekalipun kata بحر pada hakikatnya merupakan ism (kata benda). Sehingga, kalimat tersebut bermakna "air yang asin". ${ }^{16}$

Selanjutnya terdapat istilah lain yang juga berkaitan dengan laut, yaitu terma "kelautan". Meskipun istilah ini tidak ditemukan padanannya di dalam Alquran (misalnya البحرية), namun istilah ini populer dipergunakan di bidang sains kelautan karena sifat komprehensifitas yang terkandung dalam bentukan istilah tersebut. ${ }^{17}$ Kata ini berasal dari kata "laut" yang mendapatkan imbuhan "ke" dan "an". Istilah "kelautan" - menurut Tim Penyusun Kamus Pusat Pembinaan dan Pengembangan Bahasa Indonesia - secara umum dipahami sebagai "hal-hal yang berhubungan dengan laut." Sedangkan "laut" sendiri bermakna kumpulan air asin (dalam jumlah yang banyak dan luas) yang menggenangi dan membagi daratan atas benua. ${ }^{18}$ Atau dengan pernyataan lain, laut adalah bagian dari bumi yang tertutup oleh air asin.

Dari beberapa pengertian makna dan istilah tentang "laut dan kelautan" di atas tampak perbedaan antara makna "laut" di satu sisi, dan makna "kelautan" di sisi lain. Perbedaan di atas dapat dipahami dengan jelas bila ditinjau dari aspek morfologi. Kata "laut" diberi makna kumpulan air asin (dalam jumlah yang banyak dan luas) yang menggenangi dan membagi daratan atas benua. 
Oleh karena "laut" merupakan kata benda dasar (nomina), maka pemaknaan di sini menerangkan kata benda "laut" tersebut. Sedangkan kata "kelautan" diberi makna "hal-hal yang berhubungan dengan laut", karena imbuhan "ke" dan "an" pada kata "laut" di sini berfungsi sebagai ajektiva, sekalipun pada hakikatnya kata kelautan itu sendiri secara morfologis merupakan bentuk nomina.

\section{b. Bentuk-bentuk Kata Ba¥r (Laut)}

Kata $b a ¥ r$ di dalam Alquran mempunyai bentuk isytiq $\pm q^{19}$ (derivasi) yang beragam. Secara umum kata tersebut terdistribusi sebagai berikut:

(1) Bentuk بحر (mufrad/ tunggal-tanpa memperhatikan i'rab (kedudukannya dalam kalimat) - sebanyak 33 kali tersebar dalam 21 surah; yaitu QS. al-Baqarah (2/87):50 dan 164; QS. al-M \pm 'idah (5/112):96; QS. al-An' \pm m (6/55):59, 63, dan 97; QS. al-A'r $\pm f$ (7/39):138 dan 163; QS. Y-nus (10/51):22 dan 90; QS. Ibr $\pm h^{3} \mathrm{~m}$ (14/72):32; QS. al-Na¥1 (10/51):14; QS. al-Isr $\pm^{\prime}$ (7/50):66, 67, dan 70; QS. al-Kahfi (18/69):61, 63, 79, dan 109 terdapat dua kata بحر; QS. ${ }^{\circ} \pm \mathrm{h} \pm$ (20/45):77; QS. al- | ajj (22/103):65; QS. al-N-r (24/102):40; QS. al-Syu'ar $\pm^{\prime}$ (26/47):63; QS. al-Naml (27/48):63; QS. al-R-m (30/84):41; QS. Luqm \pm n (31/57):27 dan 31; QS. al-Sy-r \pm

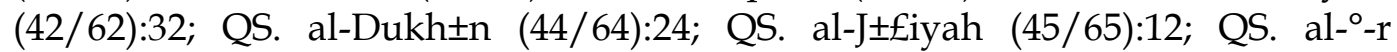
(52/76):6 dan QS. al-Ra¥m $\pm n$ (55/97):24. Tidak terdapat perbedaan tasrif (bentuk kata) dalam pengungkapan kata بحر pada setiap ayat dan surat di atas. Perbedaan dapat ditemukan pada segi $i^{\prime} r \pm b$ (perubahan baris pada akhir kata بك) serta pada segi ma'rifah dan nakirah-nya. Namun perbedaan ini tidak berimplikasi terhadap adanya perubahan makna konteks ayat, sehingga di sini tidak perlu dibicarakan lebih lanjut.

(2) Bentuk بحرين atau (bentuk tafniyyah/dual) tersebar dalam lima surah. Bentuk بحران sebuah, yaitu QS. Fttir (35/):12 dan bentuk بحرين empat buah, yaitu QS. al-Kahfi (18/69):60; QS.al-Furq \pm (25/):53; QS. al-Naml (27/):61 dan QS. alRahm \pm n (55/97):19.

(3) Bentuk بحار atau (bentuk jama'/plural) tiga buah. Bentuk بحار dua buah, QS. al-Takw³ (81/):6 dan QS. al-Infit \pm r (82/):3, serta bentuk أبحر sebuah, yaitu QS. Luqm \pm n (31/57):27. ${ }^{20}$

Kaidah tafsir menjelaskan bahwa penyebutan suatu kata tertentu dalam Alquran secara berulang-ulang (banyak) berfungsi mengokohkan suatu permasalahan dalam hati masyarakat, serta menunjukkan pentingnya permasalahan yang tersembunyi di balik kata tersebut agar mendapatkan perhatian (li al-tawk ${ }^{3} d$ wa al-tanb $\left.{ }^{3} h\right) .{ }^{21}$ Demikian pula kata بحر dan semua bentuk derivasinya. Kata بحر yang berarti "laut" ini merupakan salah suatu gagasan Alquran yang disampaikan-secara berulang-ulang-kepada masyarakat, sehingga dengan begitu gagasan tersebut perlu mendapatkan tempat yang kokoh dalam pikiran dan hati untuk direnungkan serta penting untuk diperhatikan secara seksama. Salah satu bukti bahwa laut perlu dikaji secara 
mendalam ditunjukkan oleh luasnya wilayah laut itu sendiri dibanding wilayah darat bila dilihat dari permukaan planet bumi.

Pengkajian terhadap masalah "laut" menurut pandangan Alquran menjadi lebih penting. Oleh karena Allah swt. sendiri pernah bersumpah dengan menggunakan laut sebagai media sumpah (مقسَمَ به). Hal ini menunjukkan perhatian Allah terhadapnya, QS. al-º-r (52/76):6 والبحرب, ('dan demi laut yang di dalam tanahnya ada api '). ${ }^{22}$ Ayat ini mengisyaratkan adanya aktifitas eksplorasi dan eksploitasi laut bagi kesejahteraan umat manusia.

\section{Pemanfaatan Potensi ${ }^{23}$ Laut}

Sebagai tempat tinggal dan tempat kediaman, bumi dilengkapi dengan berbagai fasilitas dan sarana penunjang kehidupan manusia. Secara umum, hal ini dinyatakan Allah swt. dalam firman-Nya QS. al-Baqarah (2/87):29 (Dia-lah Allah yang menjadikan segala yang ada di bumi untuk kamu)." 24 Dalam ayat ini Allah menegaskan, bahwa bumi dan segala isinya, termasuk wilayah bumi yang berupa lautan, diciptakan dengan kodrat untuk manusia. Karena itu manusia dapat menguasai dan memanfaatkan potensi alam untuk kepentingan tugas dan kehidupannya. ${ }^{25}$

M. Quraish Shihab, ketika mengomentari ayat di atas, menyatakan bagaimana kalian kafir, padahal Allah bukan hanya menghidupkan kamu di dunia, tetapi juga menyiapkan sarana kehidupan di dalamnya. Dia yang menciptakan untuk kamu apa yang ada di bumi semua, sehingga semua yang kamu butuhkan untuk kelangsungan dan kenyamanan hidup tersedia dan terhampar, dan itu adalah bukti ke-Mahakuasaan-Nya. Yang kuasa melakukan hal itu pastilah kuasa untuk menghidupkan yang mati. ${ }^{26}$ Ayat ini dipahami oleh banyak ulama sebagai petunjuk bahwa pada dasarnya segala apa yang terbentang di bumi ini dapat digunakan oleh manusia, kecuali jika ada dalil lain yang melarangnya. ${ }^{27}$

Selanjutnya, Seyyed Qu-ub (w. 1966 M./1376 H.) dalam tafsirnya berkomentar, bahwa pesan ayat ini adalah bumi diciptakan buat manusia. Kata "buat kamu" di sini adalah buat manusia. Perlu digarisbawahi bahwa Allah menciptakan bumi agar manusia berperanan sebagai khalifah, berperanan aktif di persada bumi ini dan berperan utama dalam pengembangannya. Manusia adalah pengelola bumi dan pemilik alat, bukan dikelola oleh bumi dan menjadi hamba yang diatur atau dikuasai oleh alat. Tidak juga tunduk pada perubahan dan perkembangan yang dilahirkan oleh alat-alat, sebagaimana diduga bahkan dinyatakan oleh paham materialisme. ${ }^{28}$

Demikian pula dengan laut yang merupakan salah satu bagian dari wilayah bumi. Laut yang dianugerahkan oleh Allah buat manusia tersebut di mana di dalamnya mengandung berbagai sumber daya alam laut yang sangat berharga, sudah sewajarnya dieksplorasi, dikelola, dan dimanfaatkan seoptimal mungkin, untuk memenuhi kebutuhan hidup dan kesejahteraan masyarakat. Di 
samping itu, pengelolaan potensi kelautan secara profesional oleh Negara dapat digunakan untuk menunjang perekonomian Nasional.

Sesungguhnya, perhatian manusia terhadap kehidupan di laut tidak terbatas pada keingintahuannya secara ilmiah tentang berbagai jenis kehidupan di dalamnya, sehingga kemudian dapat dihimpun pengetahuan yang disebut biologi laut. Tetapi perhatian tersebut telah dimulai jauh sebelum manusia menyadari bahwa di dalam laut terdapat begitu banyak jenis kehidupan yang rumit. Sejak manusia mengenal lautan, sejak itu pula ia mengetahui bahwa laut tidak saja dapat diarungi untuk mencapai benua yang belum ia kenal, tetapi juga di situ terdapat sumber makanan yang melimpah berupa ikan yang dapat dimakan. Kini manusia mengetahui bahwa laut bukan saja sebagai sumber makanan dan media angkutan, tetapi lebih dari itu laut menjadi tempat rekreasi, sumber perikanan komersial, pertambangan, sumber air tawar, sumber tenaga listrik, budidaya laut, bioteknologi, dan sumber pengembangan ilmu kelautan. ${ }^{29}$

Lebih jauh potensi kelautan yang dimaksudkan adalah sumber daya kelautan dan perikanan yang sangat kaya dan beragam. ${ }^{30}$ Secara umum, sumber daya tersebut ada yang dapat diperbaharui (renewable resources), seperti sumber daya perikanan (perikanan tangkap, budidaya, industri pengolahan dan bioteknologi, mangrove), energi gelombang, pasang surut air; dan ada juga yang tidak dapat diperbaharui (non-renewable resources) seperti sumber daya minyak dan gas bumi serta berbagai jenis mineral. Selain dua jenis sumber daya tersebut, juga terdapat berbagai jasa lingkungan kelautan seperti pariwisata bahari, industri maritim, jasa angkutan, dan sebagainya. ${ }^{31}$ Hal ini semua dapat dikembangkan dan diupayakan pemanfaatannya secara optimal guna pembangunan kehidupan bahari dalam rangka pembangunan nasional.

\section{Ragam Pemanfaatan Potensi Laut}

Setelah menyinggung gambaran potensi bahari yang disebutkan di atas, maka dalam bagian ini pembahasan diarahkan kepada penggalian informasi dari ayat-ayat Alquran yang mengemukakan ragam potensi sumber daya laut.

a. Laut Sumber Makanan Halal, Lezat dan Bergizi

Kebutuhan akan pangan yang diperoleh manusia di darat makin terasa berkurang dari hari ke hari. Hal ini disebabkan makin bertambahnya jumlah penduduk dunia yang begitu cepat, sehingga tidak saja lahan penghasil pangan seperti hutan, sawah, kolam, dan pantai berkurang karena diubah menjadi tempat pemukiman dan keperluan lain, tetapi juga produksi pangan yang dihasilkan tidak mencukupi kebutuhan mereka.

Laut sebagai lingkungan hidup berbagai jenis biota laut berpotensi untuk dijadikan sumber pangan yang berlimpah. Hal ini tentu menawarkan kesempatan yang besar kepada manusia untuk dimanfaatkan. Sebenarnya biota laut sebagai sumber daya hayati sudah berabad-abad dimanfaatkan manusia melalui kegiatan perikanan yang makin hari makin berkembang, baik dilihat dari wilayahnya maupun intensitas penangkapannya. ${ }^{32}$ 
Pembahasan mengenai laut sebagai sumber makanan halal, lezat, dan bergizi di sini difokuskan pada informasi yang dapat digali dari QS. al-M \pm 'idah (5/112):96

Dihalalkan bagimu binatang buruan laut dan makanan (yang berasal) dari

laut sebagai makanan yang lezat bagimu dan bagi orang-orang yang dalam perjalanan. ${ }^{33}$

Ayat di atas menegaskan bahwa binatang buruan dan makanan yang berasal dari laut diperbolehkan untuk dimakan sebagai makanan yang halal, lezat dan bergizi. Dr. Wahbah al-Zu¥ail ${ }^{3}$ mengartikan صَيْد الْبْرِ yang diburu dari laut, yang biasanya hidup dan hanya dapat hidup di dalamnya, seperti ikan. Hal ini berbeda dengan binatang yang dapat hidup di dua alam, baik di laut maupun di darat, seperti kepiting. Selanjutnya, Wahbah mengartikan طَعَمَ sebagai makanan yang ditemukan di lautan, baik berupa binatang (ikan) hidup atau mati-berdasarkan Hadis Nabi saw. yang diriwayatkan oleh Ab- Hurairah, bahwa laut itu suci airnya dan halal bangkainya ${ }^{34}$ - maupun berupa tumbuhan laut yang mengapung di permukaan air laut. ${ }^{35}$ Ini semua dihalalkan oleh Allah swt. untuk dimanfaatkan oleh orang yang sedang bermukim maupun yang sedang berada dalam perjalanan. Orang yang bermukim dapat mengkonsumsi binatang buruannya; ikan segar. Sedangkan orang yang bepergian dapat mengkonsumsi ikan segar jika ia sedang melakukan perjalanan di laut, atau ikan buruan tersebut diawetkan. Dengan demikian, ikan-ikan yang diburu dari laut bermanfaat sewaktu dalam perjalanan maupun di rumah, baik untuk dikonsumsi maupun disimpan, atau ikan tersebut dimanfaatkan untuk keperluan lain seperti; mengambil minyak ikan atau memanfaatkan tulangnya. ${ }^{36}$

(1) Perikanan

Berkaitan dengan perikanan, Allah swt. memberikan informasi dalam QS. al-Na¥l (16/70):14

Dan Dia-lah Allah yang menundukkan lautan (untukmu) agar kamu dapat memakan daripadanya daging yang segar (ikan) . ...37

Dalam ayat di atas terdapat kata kunci yang mengindikasikan salah satu ragam potensi kelautan, yaitu berupa perikanan yang dapat dieksplorasi dari

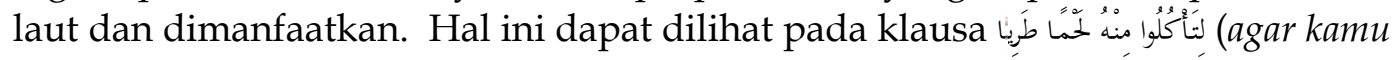
dapat memakan daripadanya daging yang segar ). ${ }^{38}$

Dari klausa tersebut dapat dipahami bahwa dengan ditundukkannya laut oleh Allah, manusia dapat memenuhi kebutuhan hidupnya dengan cara mengail dan menangkap ikan-ikan yang berada di dalam laut, ${ }^{39}$ dan Allah membolehkannya untuk dikonsumsi oleh manusia, baik dalam kondisi hidup maupun mati. ${ }^{40}$ Berkaitan dengan gambaran tentang daging segar (ikan), tersirat Kemahakuasaan Allah dalam mengeluarkan sesuatu yang lezat dari sesuatu yang asin, dan ikan-ikan tersebut segera diolah (dimasak), agar tidak menjadi rusak. Hal ini juga merupakan rangkaian nikmat Allah yang diberikan kepada umat manusia ${ }^{41}$ supaya mereka bersyukur kepada-Nya. 
Dalam pada itu, hasil laut terutama ikan mempunyai peranan dan kedudukan yang sangat penting sebagai sumber gizi. Ikan memiliki kandungan protein yang cukup tinggi (basah sekitar 17\% dan kering $40 \%$ ) dan memiliki susunan gizi yang cukup baik. Ikan juga merupakan sumber vitamin A, besi, iodium, seng, selenium, dan kalsium yang keseluruhannya mempunyai hubungan dengan kekurangan gizi mikro. Dengan kandungan zat gizi tersebut, ikan mempunyai potensi cukup baik untuk menanggulangi masalah kurang gizi, seperti kurang energi dan protein, kurang vitamin A, anemia gizi dan gangguan akibat kurang iodium yang merupakan masalah gizi utama di Indonesia. Kandungan lemak ikan umumnya rendah dibanding makanan hewani lainnya dan sebagian asam lemak pada ikan berupa asam lemak omega-3 yang sangat penting untuk proses tumbuh dan berkembangnya sel-sel syaraf termasuk sel otak pada bayi yang berlangsung dua tahun pertama, ${ }^{42}$ dan bermanfaat pula untuk mencegah hyperkolesterolemia yang berkaitan dengan beberapa penyakit degeneratif. 43

Dari gambaran di atas dapat terlihat betapa besarnya potensi kelautan dari sektor perikanan. Eksplorasi dan pemanfaatan secara optimal terhadap sektor ini tidak saja dapat memperbaiki dan meningkatkan kesehatan serta perekonomian masyarakat, tetapi juga berdampak bagi peningkatan kualitas SDM Indonesia dan pertumbuhan ekonomi nasional ke depan.

(2) Tumbuhan Laut

Selain kelompok hewan yang hidup di laut, terdapat pula kelompok tumbuhan yang disebut tumbuhan laut yang juga banyak memiliki nilai gizi dan ekonomi. Informasi mengenai tumbuhan laut tampaknya dapat pula dikaitkan dan digali dari kata طَعَمَ dalam QS. al-M土'idah:96 sebagaimana telah disebutkan sebelumnya.

Salah satu produk yang sudah lama diketahui manfaatnya adalah MakroAlgae Laut yang dikenal dalam dunia perdagangan dengan sebutan rumput laut atau Seaweed. Dari hasil analisis terhadap sembilan jenis rumput laut menunjukkan bahwa kandungannya meliputi karbohidrat berkisar antara 39\% $51 \%$, protein antara $17,2 \%-27,15 \%$, lemak berkisar antara $0,08 \%-1,9 \%$, vitamin A, B1, B2, B6, B12, dan C, serta mineral kalium, kalsium, phospor, natrium, ferrum, dan iodium. Masyarakat wilayah pantai terutama di negara-negara Asia Pasifik telah terbiasa menjadikan rumput laut sebagai makanan. Di Jepang, lebih dari sekitar 100 jenis rumput laut telah dimanfaatkan secara tradisional sebagai makanan. Dari hasil penelitian Departemen Kesehatan Jepang menyatakan bahwa agar-agar merupakan makanan yang mengandung serat tinggi, sehingga dianjurkan untuk dikonsumsi sebagai pencegah penyakit kanker usus, wasir, serta mencegah kegemukan. Di Indonesia, sebanyak 61 jenis rumput laut telah dimanfaatkan sebagai makanan, antara lain dimanfaatkan dalam bentuk salad, sup, lalapan, acar, dan dimasak sebagai sayur santan, di samping sebagai makanan seperti agar-agar, kue, dan manisan. Bahkan dalam industri makanan dan minuman, agar-agar dan keraginan biasanya diproduksi dalam bentuk dietic 
foods, yang juga digunakan dalam pembuatan minuman susu coklat, yoghurt, ice cream, jelly, puding, dan juga dibuat ramuan obat tradisional. ${ }^{44}$

Banyak jenis rumput laut yang berkhasiat sebagai obat. Sekitar 75\% terdapat di Indonesia. Beberapa marga yang disebutkan sebagai obat untuk anti kesuburan, anti tumor, penyakit jantung dan menurunkan darah tinggi adalah marga-marga Acanthophora, Hypnea, Dictyopteris, Sargassum, Stylophora dan Ulva. Selanjutnya Porphyra tenera dan Laminaria japonica adalah rumput laut yang digunakan sebagai obat tradisional. Yang pertama digunakan untuk pengobatan penyakit hipertensi dengan beri-beri atau kaki bengkak, dan yang kedua untuk menormalkan tekanan darah dan mencegah pengerasan pembuluh darah serta menurunkan kolesterol darah. 45

Dalam pada itu, pemanfaatan potensi sumber hayati perairan Indonesia ditinjau dari aspek sosial ekonomi masih banyak yang belum digarap secara maksimal. Sumber hayati perairan di samping sebagai sumber bahan pangan dan sumber bahan baku industri penting seperti industri pengolahan ikan, bahan pertanian (tepung ikan), bahan industri (minyak ikan, kulit ikan, perekat, mutiara), bahan obat-obatan (minyak hati ikan, insulin, chlorophyl), juga merupakan sumber lapangan kerja dan perluasan lapangan usaha yang bervariasi. Namun demikian, keadaan kemiskinan struktural masyarakat nelayan merupakan titik pangkal penghambat upaya peningkatan pemanfaatan sumber hayati perairan. Mereka kurang modal, kurang terampil memilih dan menggunakan teknologi, kurang pendidikan dan keterampilan, kurang dukungan pemerintah, lemah dalam menghadapi pemilik modal, serta kurang mampu menyesuaikan diri terhadap perubahan-perubahan pembangunan. ${ }^{46}$ Dengan demikian, produksi perikanan dan tunaman laut belum mampu mencukupi kebutuhan pangan dan bahan baku industri, karena sebagian besar sumber hayati perairan belum dimanfaatkan secara optimal.

b. Laut Sumber Aneka Tambang, Minyak dan Gas Bumi, serta Mineral

Uraian difokuskan pada pengkajian QS. al-Na¥l (16/70):14

'... dan kamu mengeluarkan dari lautan itu perhiasan yang kamu pakai; dan kamu melihat bahtera berlayar padanya, dan supaya kamu mencari (keuntungan) dari karunia-Nya, dan supaya kamu bersyukur'. ${ }^{47}$

Laut tidak saja menyediakan bagi manusia sumber makanan dan obatobatan. Ia juga menawarkan keindahan yang bentuk dan mutunya beragam. Banyak jenis biota laut, terutama hewan laut yang mempunyai bentuk dan warna yang indah dan menarik perhatian manusia. Manusia menjadikan biota laut atau hasil kegiatan biologiknya sebagai koleksi untuk hobi, sebagai perhiasan untuk dipakai, atau sebagai hiasan di salah satu ruangan tempat tinggal, gedung dan perkantoran. ${ }^{48}$ Selain biota laut, juga terdapat abiota laut yang juga dapat digunakan sebagai perhiasan seperti mutiara $\left(a l-l u^{\prime} l u^{\prime}\right)$ dan permata (al-marj $\pm n),{ }^{49}$ hal ini sebagaimana dinyatakan dalam QS. al-Ra¥m $\pm n$ (55/97):19-22 ('Dia membiarkan dua lautan mengalir yang keduanya kemudian bertemu, antara keduanya ada batas yang tidak dilampaui oleh masing-masing. Maka 
Al-Fikra: Jurnal Ilmiah Keislaman, Vol. 4, No. 2, Juli-Desember 2005

nikmat Tuhan kamu yang manakah yang kamu dustakan? Dari keduanya keluar mutiara dan marjan.'). ${ }^{50}$

QS. al-Na¥1 (16/70):14 yang telah dikemukakan di atas menyatakan bahwa dengan ditundukkannya lautan oleh Allah swt., maka manusia dapat menggali potensi kelautan. Adapun potensi kelautan yang terkait di sini dapat berupa bahan tambang, ${ }^{51}$ minyak dan gas bumi, mineral serta harta karun yang belum ditemukan yang terpendam di dasar laut.

Berkaitan dengan bahan tambang, filum Coelenterata (hewan karang) membentuk bangunan keras dari kapur di bawah laut yang ukurannya besar sekali, dan seringkali sebagian muncul di permukaan laut dan membentuk beting-beting karang dan bahkan pulau-pulau karang, dan mampu menenggelamkan kapal jika ditabrak. Bangunan karang yang dinamakan terumbu karang52 ini dimanfaatkan secara tradisional untuk bahan bangunan, seperti bahan semen, ubin dan genting. Pasir yang diambil dari terumbu karang digunakan sebagai bahan bangunan dan campuran semen. Sebenarnya terumbu karang ini sama sekali bukan bahan tambang yang dapat diambil begitu saja. Tetapi jauh lebih penting dari itu, terumbu karang ini sebagai salah satu jenis ekosistem laut yang melindungi banyak sekali jenis biota laut, sehingga keanekaragaman jenis ekosistem ini sangat tinggi, tertinggi di antara ekosistemekosistem yang terdapat di laut. ${ }^{33}$ Indonesia sebagai negara tropis, perairan pantainya dangkal. Oleh karena itu perairannya banyak dihuni oleh terumbu karang, yang merupakan "rumah" ikan dan biota laut lainnya. ${ }^{54}$

Lebih lanjut, manfaat terumbu karang dilihat dari sisi sebagai bahan tambang adalah bahwa ia dapat digunakan sebagai bahan bangunan. Batu-batu karang mati banyak diambil dari terumbu karang untuk bahan produksi kapur, bahan bangunan sebagai pengganti batu bata, untuk konstruksi, untuk produksi kalsium karbonat dan untuk penahan gelombang. Di samping itu, pasir dari karang juga banyak ditambang untuk produksi kapur untuk pertanian dan bahan campuran pembuat semen. Demikian pula banyak batu-batu karang yang digunakan untuk bahan pengisian daerah reklamasi pantai.

Pemanfaatan karang untuk bahan bangunan biasanya dilakukan oleh masyarakat pantai, terutama mereka yang tinggal di pulau-pulau terpencil, yang jauh dari pusat perkotaan. Menurut hasil penelitian di Kepulauan Karimunjawa, penambangan karang tersebut dilakukan sesuai pesanan dan dijual dengan harga Rp. 7.000,-/meter kubik. Harga ini jauh lebih murah bila dibandingkan dengan harga batu bata saat itu, yaitu Rp. 50.000,-/meter kubik. ${ }^{55}$

Selanjutnya, di dasar laut juga menyimpan banyak kandungan minyak dan gas bumi serta mineral dalam jumlah besar. Informasi mengenai hal ini dapat

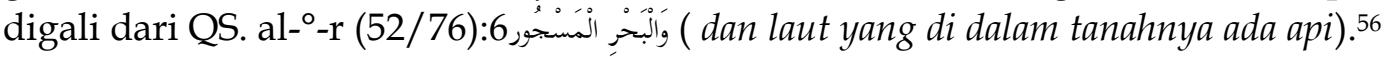
Ayat ini mengisyaratkan dapat dilakukannya eksplorasi mineral yang berada di dasar lautan yang dipergunakan bagi kesejahteraan umat manusia. Ayat-ayat lain senada yang juga menyiratkan adanya kandungan minyak, gas bumi dan mineral dalam laut, yaitu QS. al-Takw³ (81/7):6 وإذا البحار سجرت 6) (dan lautan bila telah 
diluapkan') dan QS. al-Infi ${ }^{-}$Ir (82/82):3 وإذا البحار فجرت ('dan lautan bila telah terpancar'). Kedua ayat ini mengemukakan bahwa laut mengandung berbagai potensi sumber daya alam, seperti aneka tambang, minyak dan gas bumi, serta mineral yang penting untuk menunjang aktifitas kehidupan umat manusia. ${ }^{57}$

Kata فجر yang digunakan dalam QS. al-Takw³ (81/7):6 dan QS. alInfi $^{-} \pm r$ (82/82):3-yang disebutkan di atas-menarik untuk diperhatikan. Dilihat dari bentukannya, kedua kata tersebut mempunyai persamaan bin $\pm^{\prime}$ (struktur pada 'ayn dan lam fi'l-nya) " جر " dan perbedaan huruf di awal kata. Meskipun para ulama tafsir menerjemahkan kedua kata tersebut dengan makna yang sama (meluap), tetapi keduanya mengungkapkan penekanan makna yang berbeda. Kata سجر bermakna dasar "penuh", "bercampur", dan "menyala". 58 Sedangkan kata فجر bermakna dasar "pecah" (terbelah), dan "memancar".59 Perbedaan makna dari kedua kata ini bila dihubungkan memberikan pemahaman bahwa "eksplorasi dan eksploitasi" terhadap lautan oleh manusia, akan menimbulkan pancangan-pancangan yang ditancapkan oleh anjungan pengeboran minyak di dasar lautan, dan akibatnya laut menjadi terbelah dan memancarkan isinya.

Di samping itu, kata dasar سجر dalam kedua ayat di atas; QS. al-Takw ${ }^{3} \mathrm{r}$ (81/7):6 dan QS. al- ${ }^{\circ}-\mathrm{r}$ (52/76):6, dapat pula mengandung makna laut menyala. Yang pertama " menggambarkan "proses yang terjadi secara berangsurangsur", dan yang kedua "مسجور" mengandung "makna sifat". Dengan demikian, QS. al-Takw³ ${ }^{3}$ (81/7):6 dan QS. al- ${ }^{\circ}-\mathrm{r}$ (52/76):6 mengisyaratkan proses eksplorasi dan eksploitasi sumber daya minyak, gas bumi, dan mineral dari dasar laut secara kontinyu dan terus-menerus, setelah sekian lama laut akan menyala memancarkan kandungannya (مسجور) yang panas. ${ }^{60}$ Kedua ayat ini menunjukkan eksplorasi yang dilakukan di dasar lautan akan menyemburkan kandungan minyak dan gas bumi, di mana semua zat ini berguna bagi umat manusia sebagai bahan bakar untuk menunjang aktifitas kehidupannya.

Sebagai gambaran mengenai besarnya kandungan minyak dan mineral di dasar laut ditunjukkan oleh kondisi dasar laut di Indonesia. Indonesia merupakan pertemuan tiga lempeng tektonik dunia yang menyebabkan timbulnya gunung berapi yang kaya dengan mineral logam seperti emas, perak, timah, timbal, tembaga, nikel. Dari 60 cekungan minyak dan gas di seluruh wilayah Indonesia, 70\% berada di laut, dan cadangan minyak bumi sebesar 9,1 miliar barel sebagian besar berada di perairan lepas (off shore). ${ }^{61}$ Ini menunjukkan bahwa betapa besarnya potensi kelautan, khususnya minyak, gas bumi dan mineral yang berada di wilayah Indonesia. Pengelolaan yang baik dengan berwawasan lingkungan terhadap potensi ini diharapkan mampu memberikan sumbangan devisa yang besar guna menunjang pembangunan ekonomi nasional.

c. Laut sebagai Infrastruktur (Prasarana) Transportasi 
Uraian mengenai laut sebagai prasarana transportasi di sini dapat diangkat dari penafsiran terhadap QS. al-M $\pm^{\prime}$ idah (5/112):96

Dihalalkan bagimu binatang buruan laut dan makanan (yang berasal) dari

laut sebagai makanan yang lezat bagimu dan bagi orang-orang yang dalam

perjalanan. ${ }^{62}$

Penafsiran laut sebagai prasarana transportasi dikaitkan pada kata السَََّّرَّة Menurut al-Qur ${ }^{-} \mathrm{ub}^{3}$ (w. 671 H.), kata السََّّارة memiliki dua makna; pertama, bermakna musafir (orang yang bepergian) sebagai lawan dari mukim (orang yang menetap). Yang kedua, kata ini dapat diberi makna sebagai aktifitas "pengangkutan" dengan didasarkan pada $a s b \pm b$ al-wur-d (latar belakang peristiwa) Hadis yang diriwayatkan oleh al-Nas $\pm^{\prime 3}$ dan $\mathrm{M} \pm$ lik, berkaitan dengan pertanyaan seorang sahabat yang sedang melakukan perjalanan di tengah lautan. Sementara ia hanya membawa air tawar untuk minum dalam jumlah terbatas. Ketika datang waktu salat, haruskah ia menggunakan air yang sedikit tersebut untuk berwudu dengan menaggung resiko kehausan, ataukah ia berwudu saja dengan menggunakan air laut ? Nabi menjawab: "Air laut itu suci dan bangkainya halal dimakan". ${ }^{63}$

Dengan demikian dari uraian di atas dapat dipahami bahwa salah satu manfaat laut ialah ia dapat digunakan sebagai infrastruktur yang dapat menunjang terselenggaranya suatu proses usaha maupun pembangunan. Karena ia merupakan jalan yang dapat menghubungkan satu tempat dengan tempat yang lain. Manfaat seperti ini menjadikan laut dapat dilalui kapal-kapal sebagai sarana distribusi dan transportasi.

\section{Pemenuhan Kebutuhan Hidup}

Sebelum membicarakan salah satu upaya pemanfaatan potensi kelautan untuk memenuhi kebutuhan hidup masyarakat, ada baiknya penulis

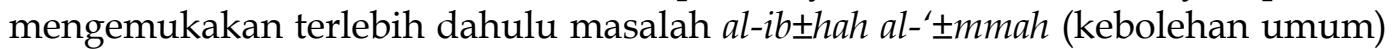
dengan maksud untuk memberikan bingkai Qurani bagi upaya pemanfaatan dan pengelolaan potensi kelautan itu sendiri. Karena seperti kata Emil Salim, kebanyakan sumber daya alam yang relevan bagi krisis lingkungan, pada umumnya tidak dimiliki oleh manusia perorangan. Udara, air, hutan, sungai, laut, dan sumber alam yang lainnya penting untuk kelestarian lingkungan, pada umumnya tidak dimiliki perorangan. Oleh karena itu timbul kecenderungan untuk menggunakannya secara boros dan tidak bertanggungjawab. Mengambil seenaknya secara gratis dari alam tanpa membayar. ${ }^{64}$ Sumber daya alam yang tidak dimiliki oleh manusia perorangan di sini, oleh Soemarwoto, disebut sebagai "sumber daya umum",65 yang maksudnya sepadan dengan apa yang dalam istilah hukum Islam disebut dengan al-ib \pm hah al- \pm mmah (kebolehan umum).

Dilihat dari perspektif hukum Islam, dasar hukum kebolehan pemanfaatan seluruh sumber daya alam ini adalah firman Allah QS. al-Baqarah (2/87):29 (Dia-lah Allah, yang menjadikan segala yang ada di bumi untuk kamu).66 
Selain ayat di atas, terdapat ayat lain yang juga mendukung kebolehan memanfaatkan seluruh sumber daya alam, baik yang ada di langit maupun di

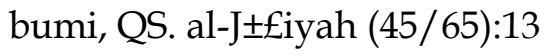

Dan Dia menundukkan untukmu apa yang ada di langit dan apa yang ada di bumi semuanya. ${ }^{6}$

Berdasarkan kedua ayat ini, para ulama merumuskan kaidah الاصلِ الاشياء الاباحة (pada dasarnya terdapat kebolehan di dalam segala hal). Kaidah inilah yang menjadi dasar dalam menetapkan istish $\pm b$ al-¥ukm, yakni tetapnya hukum sesuatu yang dibolehkan sebelum ada dalil yang menunjukkan ketidakbolehannya. Inilah yang menjadi dasar adanya $m u b \pm h$.

Menurut Quraish Shihab, QS. al-Baqarah (2/87):29 di atas dipahami oleh sebagian besar ulama sebagai isyarat bahwa pada dasarnya segala apa yang terbentang di bumi ini, termasuk lautan, dapat digunakan oleh manusia kecuali jika ada dalil lain yang melarangnya. Sebagian kecil ulama tidak memahami demikian. Mereka mengharuskan adanya dalil yang jelas untuk memahami boleh atau tidaknya sesuatu, bahkan ada juga yang berpendapat bahwa pada dasarnya segala sesuatu terlarang kecuali kalau ada dalil yang menunjukkan izin untuk menggunakannya. 68

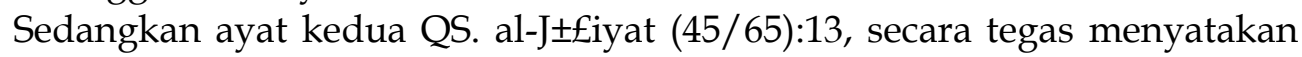
bahwa alam raya, baik wilayah udara, daratan, maupun lautan diciptakan dan ditundukkan Allah untuk manusia. Penundukan tersebut-secara potensialterlaksana melalui hukum-hukum alam yang ditetapkan Allah dan kemampuan yang dianugerahkan kepada manusia. ${ }^{69}$ Kepastian hukum-hukum alam di satu sisi dan kemampuan yang dianugerahkan Tuhan kepada manusia di sisi lain pada gilirannya melahirkan sains dan teknologi. ${ }^{70}$ Dengan sains dan teknologi, laut dikelola untuk memenuhi kebutuhan hidup manusia. Mengolah laut pada dasarnya mubah, tetapi karena tanpa diolah-dengan teknologi-laut tidak bisa memenuhi kebutuhan hidup manusia, maka mengolahnya dengan teknologi menjadi suatu tuntutan. Namun demikian, dalam mengelola laut, tidak boleh eksploitatif, menguras sumber daya alam dan mencemari lingkungan. Sebab kalau itu dilakukan, akan timbul kerusakan pada laut. Dan bila itu terjadi, maka menggunakan teknologi yang hukum dasarnya mubah, dapat berubah menjadi terlarang. Dengan demikian, pemanfaatan sumber daya yang tergolong $a l-I b \pm ¥ a h$ al-`2mmah pada dasarnya mubah, hingga ada petunjuk yang mengubahnya menjadi wajib atau haram.

Berkaitan dengan pengelolaan laut, aktifitas ini tidak boleh dilakukan secara eksploitatif, hanya menguras sumber daya alam dan mencemari lingkungan, sebab akan menimbulkan kerusakan pada laut. Allah swt. menyatakan kemurkaan-Nya kepada para pelaku perusakan di bumi (alam), agar mereka ditangkap untuk dibunuh dan disalib, supaya kejahatan tidak merajalela. Allah menegaskan dalam QS. al-M \pm 'idah (5/112):33-34

"Sesungguhnya pembalasan terhadap orang-orang yang memerangi Allah dan Rasul-Nya dan membuat kerusakan di muka bumi, hanyalah mereka 
Al-Fikra: Jurnal Ilmiah Keislaman, Vol. 4, No. 2, Juli-Desember 2005

dibunuh atau disalib, atau dipotong tangan dan kaki mereka dengan bertimbal balik, atau dibuang dari negeri (tempat kediamannya). Yang demikian itu (sebagai) suatu penghinaan untuk mereka di dunia, dan di akhirat mereka beroleh siksaan yang besar, kecuali orang-orang yang tobat (di antara mereka) sebelum kamu dapat menguasai (menangkap) mereka; maka ketahuilah bahwasanya Allah Maha Pengampun lagi Maha Penyayang." 71

Ayat di atas secara tegas menyatakan hukuman bagi orang-orang yang bertindak melampaui batas; melanggar dengan angkuh terhadap ketentuanketentuan Allah dan Rasul-Nya - yang dibahasakan oleh Alquran dengan frasa

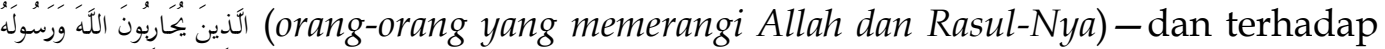
orang-orang yang berkeliaran membuat kerusakan di muka bumi-yang

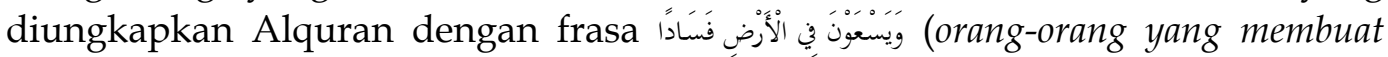
kerusakan di muka bumi) - yakni dengan melakukan pembunuhan, perampokan, pencurian dengan menakut-nakuti masyarakat, hanyalah mereka dibunuh tanpa ampun jika mereka membunuh tanpa mengambil harta. Atau disalib setelah dibunuh jika mereka merampok dan membunuh, untuk menjadi pelajaran bagi yang lain sekaligus menentramkan masyarakat bahwa penjahat telah tiada, atau dipotong tangan kanan mereka karena merampas harta tanpa membunuh, dan juga dipotong kaki mereka dengan bertimbal balik, karena ia telah menimbulkan rasa takut dalam masyarakat, atau dibuang dari negeri tempat kediamannya, yakni dipenjarakan agar tidak menakuti masyarakat, jika ia tidak merampok harta. Hukuman demikian dijatuhkan kepada mereka sebagai penghinaan di dunia, sehingga orang lain yang bermaksud jahat akan tercegah melakukan hal serupa. Di samping hukuman di dunia, mereka juga akan menanggung hukuman di akhirat, bila mereka tidak bertobat. Jika mereka bertobat sebelum tertangkap, maka Allah Maha Pengampun lagi Maha Penyayang. Karena itu hak Allah untuk menjatuhkan sanksi akan dicabut-Nya, tetapi hak manusia yang diambil oleh para penjahat yang bertobat itu harus dikembalikan atau dimintakan kerelaan pemiliknya. ${ }^{72}$

Ancaman-ancaman di atas tampaknya sangat relevan jika ditujukan pula kepada para perusak lingkungan, baik di darat maupun di laut, seperti para pelaku tindak illegal logging (pencurian kayu) di hutan, para pencuri ikan yang dilakukan nelayan asing, serta pencurian pasir laut di perairan laut Indonesia, dan lain-lain. Ancaman dengan hukum bunuh dan disalib tersebut cukup masuk akal, oleh karena tindak kejahatan mereka seperti disebutkan di atas pada dasarnya merusak ekosistem lingkungan di darat dan di laut, di mana hal ini dapat membahayakan kelestarian lingkungan yang pada akhirnya dapat mendatangkan bencana alam. Apabila bencana alam terjadi, maka ia mengakibatkan terjadinya banyak korban jiwa. Dengan begitu, sesungguhnya para penjarah, pencuri dan perampok sumber daya alamlah yang secara tidak langsung, menyebabkan umat manusia tewas menjadi korban bencana alam. Dengan demikian, para pelaku kejahatan di sini patut dihukum bunuh dan 
disalib, jika mereka tidak mau bertobat, mengembalikan sumber daya alam yang telah dirampoknya, serta memulihkan ekosistem yang telah terganggu sehingga kembali seimbang.

Dalam ayat sebelumnya, QS. al-M士'idah (5/112):32, ditegaskan bahwa seseorang yang membunuh orang lain secara zalim (bukan karena melaksanakan hukuman $q i_{i} \pm_{i}$ kepada yang dibunuh atau yang dihukum bunuh telah membuat kerusakan di muka bumi) pada hakikatnya seolah-olah ia membunuh umat manusia seluruhnya;

'... barangsiapa yang membunuh seorang manusia, bukan karena orang itu (membunuh) orang lain, atau bukan karena membuat kerusakan di muka bumi, maka seakan-akan dia telah membunuh manusia seluruhnya. Dan barangsiapa yang memelihara kehidupan seorang manusia, maka seolah-olah dia telah memelihara kehidupan manusia semuanya ... .'73

Dapat dipahami mengapa ayat di atas menegaskan ketentuan sedemikian rupa, oleh karena ajaran Alquran sangat menghormati, memuliakan, dan memandang suci kehidupan umat manusia. Sehingga seseorang yang membunuh orang lain, seolah-olah ia telah membunuh umat manusia seluruhnya. Sebaliknya, seseorang yang memelihara tangannya untuk tidak membunuh orang lain, seolah-olah ia membiarkan hidup umat manusia secara keseluruhan. Sesungguhnya kehidupan seorang manusia merefleksikan kehidupan umat manusia seluruhnya, karena pada dasarnya, mereka diciptakan berasal dari satu jiwa (nafs wæ¥idah). ${ }^{74}$ Allah memandang bahwa membunuh seseorang itu sebagai membunuh manusia seluruhnya, karena seseorang itu adalah anggota masyarakat, dan karena membunuh seseorang berarti juga membunuh keturunannya. Dengan demikian, kembali pada bahasan semula, dalam ayat ini terdapat indikasi bahwa membuat kerusakan di muka bumi, termasuk berbuat kerusakan di lingkungan laut membawa konsekwensi adanya hukum bunuh bagi pelakunya.

Selanjutnya pemanfaatan dan pengelolaan berbagai potensi kelautan yang dilakukan secara optimal dapat memenuhi kebutuhan ekonomi masyarakat. Penangkapan ikan di laut dalam rangka pemanfaatan biota laut mencerminkan kegiatan manusia sebagai pemburu. Perburuan semacam ini dilengkapi peralatan canggih, seperti mekanisasi perikanan, penggunaan alat bantu elektronik seperti radar, alat sonar, radio dan penginderaan jauh untuk menangkap hewan laut. Kegiatan semacam ini merupakan perburuan hidupanliar yang bebas berkeliaran kemana-mana di suatu perairan, dan tidak dimiliki oleh siapa pun sampai ikan-ikan tersebut tertangkap dalam jaring atau pancing seseorang. Selama masih dalam hidupanliar di laut, ikan-ikan dan biota laut lainnya menjadi milik siapa saja untuk dapat memanfaatkan. Upaya untuk menguasai sumber daya ikan ${ }^{75}$ secara besar-besaran dalam perairan luas banyak dilakukan oleh negara-negara maritim yang banyak bertumpu pada hasil perikanan untuk kepentingan bangsanya.

Sehubungan dengan pemberdayaan ekonomi masyarakat melalui pemanfaatan laut, Dr. Ir. Sahala Hutabarat M.Sc, pakar oseanografi dari 
Universitas Diponegoro Semarang menyatakan paling tidak ada 13 unsur makro penting yang harus dikembangkan dalam pembangunan kelautan dan perikanan di Indonesia saat ini. Upaya tersebut sebagai titik awal untuk meletakkan kerangka dasar agar laut benar-benar dapat dimanfaatkan secara optimal guna meningkatkan taraf hidup masyarakat dan perekonomian nasional, sekaligus memperkecil kemungkinan terjadinya disintegrasi bangsa. Ke-13 unsur penting itu antara lain bidang perikanan darat dan laut; perhubungan laut yang menyangkut pengoperasian bandar pelabuhan; pertahanan dan keamanan; industri strategis kemaritiman yang meliputi pengadaan perkapalan serta sarana dan prasarananya; serta industri pertambangan yang berkaitan dengan sumbersumber alam mineral yang kini masih belum ditangani dengan baik. Selain itu perlu dioptimalkan pariwisata bahari melalui obyek-obyek wisata laut dengan membuka pulau-pulau yang memiliki potensi wisata. Di Indonesia masih banyak pulau-pulau potensial pariwisata yang belum dibuka, apalagi dimanfaatkan dan dikembangkan dengan baik untuk kepentingan devisa. Sebagai gambaran jumlah pulau yang menjadi wilayah Indonesia sebanyak 17.508. Yang memiliki nama baru 5.707 pulau, yang belum memiliki nama jauh lebih banyak, 11.801 pulau. ${ }^{76}$

Lebih lanjut, realitas Indonesia yang merupakan negara bahari, tetapi kurang memiliki tenaga terampil di bidang kebaharian. Misalnya, jumlah ahli perikanan dan kelautan yang masih sangat terbatas. Oleh karena itu, perguruan tinggi perlu memperhatikan persoalan ini untuk menjawab kebutuhan tenaga terampil perikanan dan kelautan di masa mendatang. ${ }^{77}$

Pembinaan masyarakat nelayan juga sangat memprihatinkan. Mereka hidup dalam kesederhanaan di hampir seluruh perkampungan bahari di seantero Tanah Air. Hal ini merupakan tugas Departemen Kelautan dan Perikanan untuk meningkatkan kesejahteraan dan taraf hidup mereka sehingga bisa hidup secara layak. ${ }^{78}$ Oleh karena itu, bila upaya-upaya yang telah disebutkan di atas dilaksanakan secara konsisten dan berkelanjutan dengan melibatkan masyarakat pesisir, maka diharapkan upaya tersebut dapat memberikan peningkatan taraf ekonomi mereka secara khusus dan peningkatan perekonomian nasional secara umum

\section{Pengembangan Ilmu Pengetahuan}

Uraian pada bagian ini didasarkan pada informasi yang dapat digali dari QS. al-Baqarah (2/87):164

"Sesungguhnya dalam penciptaan langit dan bumi, silih bergantinya malam dan siang, bahtera yang berlayar di laut membawa apa yang berguna bagi manusia, dan apa yang Allah turunkan dari langit berupa air, lalu dengan air itu Dia hidupkan bumi sesudah mati (kering)-nya dan Dia sebarkan di bumi itu segala jenis hewan, dan pengisaran angin dan awan yang dikendalikan antara langit dan bumi; Sungguh (terdapat) tanda-tanda (KeEsa-an dan Kebesaran Allah) bagi kaum yang memikirkan."79 
Ayat ini merupakan salah satu rangkaian ayat-ayat yang menegaskan manfaat laut sebagai karunia Allah bagi umat manusia. Manfaat yang dimaksudkan di sini adalah laut berfungsi sebagai sumber pengembangan ilmu pengetahuan kelautan. Di samping beberapa manfaat laut yang lain, misalnya laut sebagai faktor produksi, sarana distribusi dan transportasi, sumber makanan bergizi dan kesenangan bagi manusia, sebagaimana telah disinggung sekilas sebelumnya.

QS. al-Baqarah (2/87):164 di atas menegaskan bahwa penciptaan langit dan bumi, silih bergantinya malam dan siang, dan kapal yang berlayar di lautan tidak saja membawa manfaat bagi umat manusia, tetapi juga menjadi pengajaran bagi orang-orang yang berakal. Dikatakan menjadi pengajaran bagi mereka, karena orang-orang yang berakal selalu membaca, meneliti, dan mendalami ciriciri sesuatu. Mereka membaca alam, tanda-tanda zaman, sejarah, maupun diri sendiri, baik yang tertulis maupun tidak. Oleh karena orang-orang yang berakal selalu membaca dan mengulang-ulang dalam membaca alam - sampai mencapai batas maksimal-maka mereka tidak saja memperoleh kecakapan dalam membaca, tetapi juga menghasilkan pengetahuan dan wawasan baru yang selanjutnya diupayakan pengembangannya.80 Perintah membaca ini sejalan dengan firman Allah dalam QS. al-'Alaq (96/1):1-5;

Bacalah dengan (menyebut) nama Tuhanmu Yang menciptakan, Dia telah menciptakan manusia dari segumpal darah. Bacalah, dan Tuhanmulah Yang Maha Pemurah, Yang mengajar (manusia) dengan perantaraan kalam. Dia mengajarkan kepada manusia apa yang tidak diketahuinya. ${ }^{81}$

Demikian pula terhadap laut, para ilmuwan terus melakukan penelitian terhadap obyek ini, berkisar berbagai potensi kelautan dan upaya pemanfaatannya bagi kepentingan umat manusia. Di samping untuk kepentingan pengetahuan, diperoleh pula ilmu pengetahuan kelautan yang disebut "oceanologi" dan dilakukan upaya pengembangannya. Dengan tunduknya lautan-yang terjadi secara potensial tunduk kepada hukum-hukum alam yang ditetapkan Allah, ${ }^{82}$ sebagaimana benda-benda alam lainnya yang tidak bernyawa - selain manusia diberi kemampuan untuk mengetahui ciri dan hukum-hukum yang berkaitan dengan alam raya, ${ }^{83}$ juga menjadikan ilmuwan dapat memperoleh kepastian mengenai hukum-hukum alam. Dengan fenomena ini, mereka dapat merumuskan ilmu pengetahuan kelautan secara sistematis yang dengannya mengantarkan manusia dapat memanfaatkan laut yang telah ditundukkan Tuhan itu. Keberhasilan memanfaatkan laut merupakan buah teknologi.

Lebih lanjut, Alquran sendiri memberikan perhatian yang besar terhadap ilmu. Hal ini terlihat dengan terulangnya penyebutan kata ilmu dan berbagai bentuk derivasinya sebanyak 854 kali. ${ }^{84}$ Kata ini digunakan dalam arti proses pencapaian pengetahuan dan obyek pengetahuan. Kata'ilm' ditinjau dari segi bahasa berarti kejelasan. Karena itu, ilmu merupakan pengetahuan yang jelas tentang sesuatu. ${ }^{85}$ 
Dalam pandangan Alquran, ilmu adalah keistimewaan yang menjadikan manusia unggul dibanding makhluk-makhluk lain guna menjalankan fungsi kekhalifahan. Hal ini sebagaimana tergambar dalam QS. al-Baqarah (2/87):31-32 berkenaan dengan kisah kejadian manusia pertama, Adam a.s.

"Dan Dia mengajarkan kepada Adam nama-nama (benda-benda) seluruhnya, kemudian mengemukakannya kepada para Malaikat lalu berfirman: "Sebutkanlah kepada-Ku nama benda-benda itu jika kamu memang orang-orang yang benar!". Mereka menjawab: "Maha Suci Engkau, tidak ada yang kami ketahui selain dari apa yang telah Engkau ajarkan kepada kami; sesungguhnya Engkaulah Yang Maha Mengetahui lagi Maha Bijaksana". 86

Manusia, menurut pandangan Alquran, memiliki potensi untuk menemukan ilmu pengetahuan dan melakukan pengembangan dengan izin Allah. Karena itu banyak ayat Alquran yang memerintahkan manusia untuk menempuh berbagai cara untuk mewujudkan hal tersebut, di samping pula menunjukkan tingginya kedudukan orang-orang yang memiliki ilmu pengetahuan. ${ }^{87}$

Dalam pada itu, pengembangan ilmu pengetahuan kelautan berjalan seiring dengan perkembangan teknologi pemanfaatan sumber daya laut untuk memenuhi kebutuhan hidup manusia. Oleh karena itu, aktifitas-aktifitas trial and error (coba-coba), pengamatan, percobaan, dan tes-tes kemungkinan merupakan cara-cara yang dipergunakan oleh para ilmuwan untuk meraih pengetahuan. Berbagai aktifitas ilmiah ini juga disinggung oleh Alquran yang memerintahkan manusia untuk memikirkan dan melakukan pengamatan serta penelitian terhadap alam raya. 88

Demikianlah salah satu pemanfaatan potensi kelautan, yaitu dengan melakukan pengembangan ilmu pengetahuan, khususnya di bidang kelautan. Pengembangan ilmu pengetahuan ini tentunya setelah dilakukan dan dijalani proses berbagai aktifitas ilmiah; melalui pengamatan dan penelitian terhadap lautan. Pengembangan ini tidak saja sejalan dengan perintah Alquran, tetapi juga menunjang peningkatan dan kemajuan sektor perikanan secara khusus maupun sektor-sektor lainnya dalam lingkup kelautan. Diharapkan pula dengan peningkatan pendapatan dari sektor perikanan, para nelayan-merupakan komunitas yang terlibat langsung dalam sektor kelautan - dapat terangkat status perekonomian kepada keadaan yang lebih baik, terlepas dari kemiskinan yang menderanya selama ini. Inilah tujuan ideal yang diharapkan agar alam semesta yang diciptakan Allah buat manusia dapat dimanfaatkan dengan baik demi kesejahteraannya.

\section{Penutup}

Setelah menelaah ayat-ayat Alquran berkenaan dengan "laut", maka dapat disimpulkan bahwa laut dan berbagai potensinya pada hakekatnya merupakan anugerah Allah swt. yang diperuntukkan bagi umat manusia. Penganugerahan 
ini memberikan konsekwensi bagi manusia, sebagai khalifah Allah di muka bumi, memiliki hak pengelolaan dengan melakukan eksplorasi terhadap laut guna mengambil manfaat darinya, di samping memiliki tanggung jawab (kewajiban) untuk melakukan upaya konservasinya guna menjaga keseimbangan ekologi. Upaya pelestarian tersebut tidak saja dapat memelihara kelangsungan ekologi lingkungan laut, tetapi juga kelangsungan kehidupan manusia itu sendiri dalam jangka panjang, khususnya generasi mendatang yang juga memiliki hak terhadap anugerah ini. Oleh karena itu, untuk keperluan eksplorasi tersebut diperlukan metode eksplorasi yang tepat, seimbang, dan proporsional untuk menghindari terjadinya kerusakan laut beserta isinya. Dengan demikian, manusia hendaknya tidak hanya melihat laut sebagai obyek untuk "pengkayaan diri" bagi satu generasi saja (generasinya sendiri), tanpa mempedulikan kebutuhan generasi mendatang.

Hubungan laut dan eksistensi manusia menurut Alquran dapat dijelaskan bahwa Allah swt. menciptakan manusia di muka bumi ini dan memberikan kedudukan serta fungsi yang sangat tinggi untuk mengelola dan mengatur bumi (dalam hal ini mengelola laut) untuk diambil manfaatnya. Dengan begitu, hubungan antara manusia dengan alam beserta segala isinya berada dalam kerangka istikhl $\pm f$ atau tugas-tugas kekhalifahan manusia. Inilah eksistensi manusia sesungguhnya.

Konsep kekhalifahan menjadikan faktor lingkungan sebagai pertimbangan utama dalam perencanaan dan pelaksanaan pembangunan. Dengan begitu ia tidak mengeksploitasi alam secara besar-besaran demi kepentingan manusia. Konsep kekhalifahan bersifat transenden. Artinya penguasaan manusia terhadap lingkungannya adalah amanah dari Allah, tidak mutlak dan akan dipertanggungjawabkan kepada-Nya. Itulah sebabnya prinsip yang mendasari hubungan antara manusia dengan alam tidak hanya hubungan eksploitatif, tetapi juga apresiatif. Alam tidak hanya dimanfaatkan, tetapi juga harus dihargai. Hubungan antara manusia dengan alam bukan merupakan hubungan antara penakluk dan yang ditaklukkan, atau antara tuan dengan hamba, tetapi hubungan kebersamaan dalam ketundukan kepada Allah swt. Selain itu, kemampuan manusia dalam mengelola alam bukanlah disebabkan kekuatan yang dimilikinya, tetapi disebabkan anugerah Allah swt. Jadi, intervensi Tuhanlah yang menundukkan seluruh alam untuk manusia, sehingga manusia dapat mengolahnya untuk memenuhi kebutuhan hidupnya. Dengan kata lain, alam semesta dapat dimanfaatkan oleh manusia setelah ada campur tangan aktif dari Tuhan. Tanpa upaya penundukan Tuhan, alam ini tidak mungkin dapat dimanfaatkan dengan mudah. Begitu pula dengan lautan, ia tidak begitu saja dapat dikelola dan dimanfaatkan oleh manusia dengan mudah, tetapi lautan sesungguhnya telah mengalami proses penundukan ( $\left.t a s k h^{3} r\right)$ oleh Allah swt., sehingga dapat dimanfaatkan secara optimal. Sebagai imbalannya, pengelolaan laut tersebut tentu harus dibarengi dengan tanggung jawab. Dengan demikian, alam ini adalah karya besar dari Yang Maha Kuasa, ia tidak diciptakan hanya 
untuk memperlihatkan kebesaran dan kekuasaan-Nya, tetapi untuk memenuhi kebutuhan-kebutuhan vital manusia.

\section{Catatan Akhir :}

1 Rokhmin Dahuri, “Mengembalikan Supremasi Bangsa di Lautan,” Kompas, (Jakarta), Kamis, 4 Nopember 1999, h. 4

2 A. Riza Wahono, “Tantangan dari Sektor Kelautan," Kompas, (Jakarta), Kamis, 4 Nopember, 1999, h. 4

${ }^{3}$ A. Riza Wahono, Tantangan ..., h. 4

4 A. Riza Wahono, Tantangan ..., h. 4

${ }^{5}$ Lihat Tim Penulis PTK BPPT, Profil Kelautan Nasional Menuju Kemandirian, (Bandung: Ilham Jaya, t.th.), h. 4. Bandingkan dengan Mamat Ruhimat dan Bambang Utoyo, Geografi, (Bandung: Ganeca Exact Bandung, 1994), Jilid 1, h. 113

${ }^{6}$ A. Riza Wahono, Tantangan ..., h. 4

7 A. Riza Wahono, Tantangan ..., h. 4

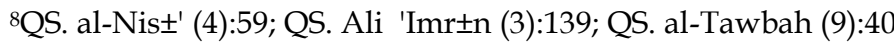

${ }^{9}$ Alquran diturunkan membawa tiga maksud utama, yaitu sebagai petunjuk bagi jin dan manusia, sebagai tanda pendukung kebenaran Nabi saw., dan agar makhluk menyembah Tuhan dengan cara membacanya. Lihat Mu¥ammad 'Abd al-' $\mathrm{A} \S^{3} \mathrm{~m}$ al-Zarq $\pm \mathrm{n}^{3}$, Man \pm hil al-' Irf $\pm n$, (Kairo: 'Is \pm al-B $\pm b^{3}$ al- $\left.\mid \mathrm{alab}^{3}, 1972\right)$, Jilid I, h. 124. Lebih rinci tentang maksud diturunkannya Alquran,

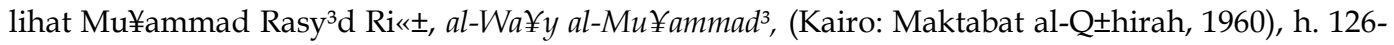
8. Di samping itu Alquran disebut $u m m$ al-Kit $\pm b$, karena ia sebagai prototipe dari segala buku ilmu pengetahuan. Lihat Sayyed Hossein Nashr, Ideals and Realities of Islam, (London: Geoerge Allen and Unwin Ltd., 1972), h. 37

10 Mujiyono Abdillah, Agama Ramah Lingkungan; Perspektif Al-Qur'an, (Jakarta: Paramadina, 2001), h. 10

11 A. Riza Wahono, Tantangan ..., h. 4

12 Kata al-ba¥r dengan berbagai bentuk derivasinya terulang sebanyak 41 kali dengan perhitungan kata tersebut dihitung dua (2) kali dalam QS. al-Kahfi (18/69):109, karena dalam ayat tersebut memang diulang dua kali. Lihat selengkapnya Mu¥ammad Fu’ $\pm d$ 'Abd al-B $\pm q^{3}$, al-Mu'jam

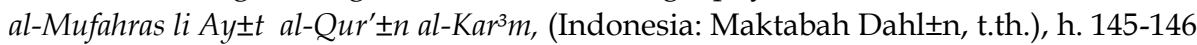

${ }^{13}$ Ahmad Warson Munawwir, al-Munawwir Kamus Arab - Indonesia (Yogyakarta: UPBIK Pondok Pesantren Al-Munawwir, 1984), h. 64

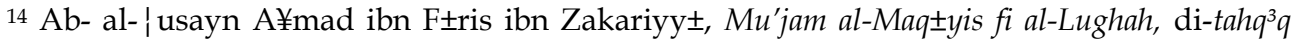
oleh Syih \pm budd³n abu 'Amr (Beirut: D \pm r al-Fikr, 1998), h. 114

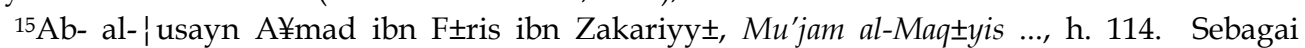
penunjang terhadap makna $b a ¥ r$ di atas, ada baiknya dilihat kalimat berikut استبحر فلان ف العلم (si fulan luas [mendalam] ilmunya).

16 Ibn Man§-r Jam $\pm l u d d^{3} n$ ibn Mukarram al-An; $\pm r^{3}$, Lis $\pm n$ al-'Arab. Dinukil dari versi CD ROM, (Mesir: al-D \pm r al-Mi;riyyah, t.th.)

${ }^{17 B a h k a n ~ i s t i l a h ~ " k e l a u t a n " ~ d i p e r g u n a k a n ~ s e b a g a i ~ n a m a ~ s e b u a h ~ l e m b a g a ~ k h u s u s ~}$ pemerintahan yang mengurusi laut, yaitu Depatemen Kelautan dan Perikanan.

18 Lihat Tim Penyusun Kamus Pusat Pembinaan dan Pengembangan Bahasa, Kamus Besar Bahasa Indonesia, (Jakarta: Balai Pustaka, 1989), h. 503. Cf. Rokhmin Dahuri, Keanekaragaman Hayati Laut, (Jakarta: Gramedia Pustaka Utama, 2003), h. 13

19 Isytiq $\pm q$ adalah mengeluarkan satu bentuk kata dari kata yang lain karena adanya persesuaian arti melalui perubahan lafal. Lihat Louis Ma'l-f, al-Munjid $f^{3}$ al-Lughah wa al-A'ltm 
(Beirut: D $\pm r$ al-Masyriq, 1981), h. 396; $\mathrm{Am}^{3} \mathrm{n} \mathrm{Al}^{3}$ Sayyid, F3 'Ilm al-\$arf, (Mesir: D $\pm r$ al-Ma' \pm rif, 1971), h. 23

${ }^{20}$ Lihat selengkapnya Mu¥ammad $\mathrm{Fu}^{\prime} \pm \mathrm{d}$ 'Abd al-B $\pm \mathrm{q}^{3}$, al-Mu'jam al-Mufahras li Ay $\pm t$ alQur' \pm n al-Kar³m, (Indonesia: Maktabah Dahl \pm n, t.th.), h. 145-146. Sebagai perbandingan, ayat-ayat yang berbicara tentang البحر (laut) berjumlah 41 ayat, sementara ayat-ayat tentang البر (darat) terulang sebanyak 12 kali, fenomena ini dapat dipandang sebagai indikasi pentingnya laut bagi kehidupan manusia.

21 A ¥mad A¥mad Badaw 3 , Min Balagh $\pm t$ al-Qur’ $\pm n$, (Kairo: D \pm r Nah«ah Mijr, 1950), h. 143

22 Departemen Agama RI., Al Qur'an ..., h. 865. Huruf “," dalam ayat di atas, di samping sebagai waw qasam, ia juga merupakan waw ' $a^{-} f$ yang bersandar (secara bertingkat) kepada ayatayat sebelumnya, khususnya ayat 1 dari QS. al- ${ }^{\circ}-\mathrm{r}$ (52/76) والطور (Lihat Ab- Ja’far A¥mad bin

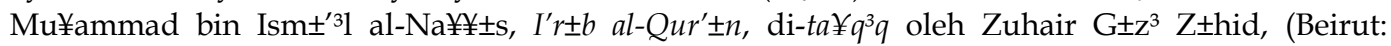
Maktabat al-Nahdiyyah al-'Arabiyyah, 1988), Juz IV,h. 253. Berdasarkan kaidah tafsir bahwa sumpah Allah dengan menggunakan makhluk-Nya mengisyaratkan arti pentingnya makhluk

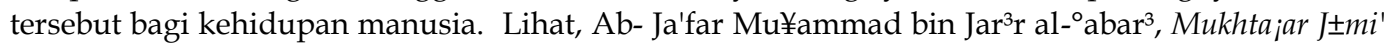
al-Bay $\pm n$ 'an Ta'w3l Ayy al-Qur' $\pm n$, (Beirut: D $\pm r$ al-Fikr, 1992), h. 523. Lihat pula Mu¥ammad Naw $\pm w^{3}$ al-J $\pm W^{3}, M a r \pm ¥ l a b^{3} d$, (Beirut: D \pm r al-Fikr, 1994), Juz II, h. 327

23 Potensi bermakna "daya, kekuatan, kemampuan, dan kesanggupan". Lihat Tim Penyusun Kamus Besar Bahasa Indonesia, Kamus Besar ..., h. 697

24 Departemen Agama RI., Al Qur'an ..., h. 13

${ }^{25}$ Abd. Muin Salim, "Metode Dakwah untuk Menanggulangi Lahan Kritis: Sebuah Telaah Qurani", Laporan Penelitian, dalam Perumusan Model Dakwah dalam Pelaksanaan Penanggulangan Lahan Kritis di Sulawesi Selatan, (Ujung Pandang: Kerjasama BAPPEDA Tkt. I Sulawesi Selatan dengan P3M IAIN Alauddin, 1989/1990), h. 86

26M.Quraish Shihab, Tafsir al-Mishbah ..., Vol. I, h. 135

${ }^{27}$ M.Quraish Shihab, Tafsir al-Mishbah ..., Vol. I, h. 136

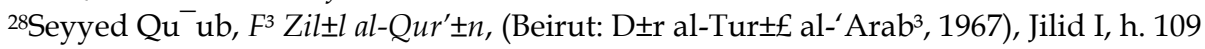

${ }^{29}$ Kasijan Romimohtarto dan Sri Juwana, Biologi Laut: Ilmu Pengetahuan tentang Biota Laut, (Jakarta: Djambatan, 2001), h. 409

30Sebagai contoh total potensi perikanan laut Indonesia sebesar 17,4 juta ton ikan pertahun dari wilayah tangkap seluas 5,8 juta km persegi (setara 580 juta hektar). Lihat Departemen Eksplorasi Laut dan Perikanan, Program dan Kegiatan: Departemen Eksplorasi Laut dan Perikanan Republik Indonesia tahun 2000-2004, (Jakarta: Departemen Eksplorasi Laut dan Perikanan RI., 2000), h. 2

31 Departemen Kelautan dan Perikanan, Sumber Daya Kelautan dan Perikanan dalam Pemberdayaan Ekonomi Nasional, makalah seminar, (Jakarta: Departemen Kelautan dan Perikanan, 2002), h. 1

32 Kasijan Romimohtarto dan Sri Juwana, Biologi Laut ..., h. 410

${ }^{33}$ Departemen Agama RI., Al Qur'an ..., h. 178

${ }_{34}$ Abdurra $¥ \mathrm{~m} \pm \mathrm{n}$ bin $\mathrm{Ab}^{3}$ Bakr Ab- al-Fa«l al-Suy- ${ }^{-3}$, Tanw ${ }^{3} r$ al- $\mid a w \pm l i k$, (Mesir: Al-Maktabah

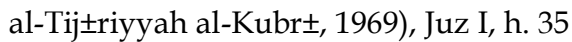

${ }^{35}$ Wahbah al-Zu¥ail ${ }^{3}$, al-Tafs ${ }^{3} r$..., Juz VII, h. 40-50

36 Wahbah al-Zu¥ail ${ }^{3}$, al-Tafs ${ }^{3} r$..., Juz VII, h. 57

37 Departemen Agama RI., Al Qur'an ..., h. 404

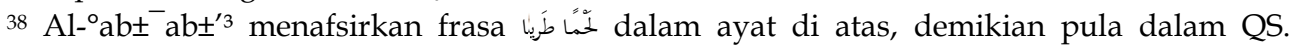
$\mathrm{F}^{-}$ir:12, tidak hanya menunjuk kepada makna "ikan (daging ikan)", tetapi bisa juga bermakna

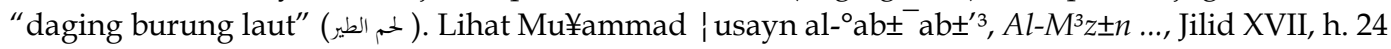
${ }^{39}$ Wahbah al-Zu¥ail ${ }^{3}$, al-Tafs ${ }^{3} r$..., Juz XIII, h. 97 
${ }^{40}$ Wahbah al-Zu $¥$ ail ${ }^{3}$, al Tafs $^{3} r$..., Juz XIII, h. 100

${ }^{41}$ Wahbah al-Zu¥ail ${ }^{3}$, al-Tafs ${ }^{3} r$..., Juz XIII, h. 100. Lihat pula Mu¥ammad al-Amn bin Mu¥ammad al-Mukht $\pm \mathrm{r}$ al-Jak ${ }^{3} \mathrm{n}^{3}$ Al-Syinq ${ }^{3}{ }^{3}, A \ll w \pm^{\prime}$ al-Bay $\pm n \beta^{3}{ }^{\prime} \ll \pm ¥$ al-Qur' $\pm n$ bi al-Qur' $\pm n$, (Beirut: $\mathrm{D} \pm \mathrm{r} I ¥ \mathrm{y}^{\prime}{ }^{\prime}$ al-Tur $\pm \mathcal{E}$ al-'Arab $\left.{ }^{3}, 1996\right)$, Jilid II, h. 125

42 Masa bayi berlangsung dua tahun pertama setelah periode bayi yang baru lahir dua minggu. Bayi berkembang pesat, baik secara fisik maupun psikologis. Dengan cepatnya pertumbuhan ini, perubahan tidak hanya terjadi dalam penampilan, tetapi juga dalam kemampuan. Meskipun pertumbuhan pesat terjadi pada seluruh periode bayi, namun yang terpesat adalah dalam tahun pertama. Lihat Elizabeth B. Hurlock, Developmental Psycology: A LifeSpan Approach, diterjemahkan oleh Istiwidayanti dan Soedjarwo dengan judul Psikologi Perkembangan: Suatu Pendekatan Sepanjang Rentang Kehidupan, edisi ke-5, (Jakarta: Erlangga, t.th.), h. 76-77

${ }^{43}$ Ikan sebagai bahan makanan mempunyai banyak kegunaan dalam hubungannya dengan gizi masyarakat. Namun pemanfaatan ikan sebagai bahan makanan utama dalam keluarga masih terbatas pada kelompok mayarakat menengah ke atas. Pada masyarakat miskin, konsumsi ikan masih di bawah kebutuhan minimal. Pada tahun 1990 ternyata sebagian besar penduduk masih menggunakan ikan sebagai sumber protein baru pada peringkat II, kecuali Maluku peringkat I, Jatim dan NTT peringkat III, Jateng peringkat IV, serta DI Yogyakarta pada peringkat V. Perkiraan masalah yang dihadapi dalam pelita VI yang berkaitan dengan perikanan adalah masih rendahnya taraf hidup para nelayan sebagai dampak belum meratanya distribusi pendapatan di samping pengolahan pascapanen dan pemasaran ikan belum dilakukan sebagaimana mestinya. Padahal salah satu faktor yang cukup penting dalam mempengaruhi kualitas SDM adalah faktor gizi sebagaimana terdapat dalam ikan. Hal ini didasarkan karena gizi mempunyai kaitan yang erat dengan angka terjangkitnya penyakit dan terjadinya kematian. Keadaan kesehatan dan gizi mempunyai peranan dan sumbangan yang cukup besar dalam usaha pencerdasan bangsa serta menunjang peningkatan produktivitas dan kreativitas penduduk. Tenaga kerja yang sehat dan yang memakan makanan yang bergizi secara fisik dan mental, lebih energik dibanding dengan tenaga kerja yang kurang sehat dan kurang gizi, dan karenanya akan lebih produktif dan inovatif.

Pembangunan kesehatan dan gizi pada dasarnya merupakan bagian integral dari pembangunan nasional, karena kesehatan dan gizi merupakan salah satu aspek dari kebutuhan pokok manusia. Dengan demikian, maka dalam rangka pengembangan mutu SDM dianggap sangat perlu meningkatkan status kesehatan dan gizi masyarakat secara menyeluruh. Permasalahan kesehatan yang akan dihadapi mendatang diwarnai oleh perubahan demografi yang dialami penduduk Indonesia sebagai akibat dari penurunan tingkat fertilitas dan angka kematian yang mendorong perubahan proporsi penduduk menurut kelompok usia. Di samping itu kita akan menghadapi masalah kesehatan dan gizi ganda, selain masalah kesehatan dan gizi kurang yang berkaitan dengan penyakit menular, juga akan dijumpai masalah penyakit tidak menular disertai dengan keadaan gizi lebih. Lihat Nur Nasry Noor, "Pembinaan Masyarakat Bahari; Suatu Tinjauan Ilmu Gizi", Makalah Seminar Sehari, menyambut Dies Natalis IAIN Alauddin Ujung Pandang ke-29 tgl. 5 Nopember 1994, h. 1 dan 6

${ }^{44}$ Nur Nasry Noor, Pembinaan Masyarakat ..., h. 7

${ }^{45}$ Selain rumput laut, terdapat tumbuhan laut lain yang juga dapat dimanfaatkan. Seperti lamun dan Mangrove. Secara tradisional lamun dimanfaatkan untk dianyam menjadi keranjang; dibakar untuk garam, soda atau penghangat; mengisi kasur; digunakan atap rumbai; bahan kemasan; kompos, isolasi suara dan suhu; pengganti benang. Sedang secara moderen, lamun dimanfaatkan sebagai penyaring limbah; stabilisator pantai; bahan untuk pabrik kertas; sumber bahan kimia penting; pupuk, makanan dan obat-obatan. Sedangkan mangrove dimanfaatkan 
untuk industri nipah; industri rokok; gula nipah; produksi alkohol. Lihat Kasijan Romimohtarto dan Sri Juwana, Biologi Laut ..., h. 413-416

${ }^{46}$ Nur Nasry Noor, Pembinaan Masyarakat ... , h. 7-8

${ }^{47}$ Departemen Agama RI., Al Qur'an ..., h. 404

${ }^{48}$ Kasijan Romimohtarto dan Sri Juwana, Biologi Laut ..., h. 431

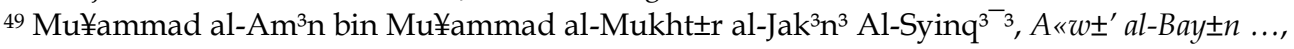
h. 125

${ }^{50}$ Departemen Agama RI., Al Qur'an ..., h. 886

${ }^{51}$ Sebagai gambaran, wilayah Indonesia yzng merupakan pertemuan tiga lempeng tektonik dunia, menyebabkan timbulnya gunung berapi yang kaya dengan mineral logam, seperti emas, perak, timah, timbal, tembaga, nikel, dan sebagainya. Lihat Departemen Eksplorasi Laut dan Perikanan, Program dan Kegiatan: Departemen Eksplorasi Laut dan Perikanan Republik Indonesia tahun 2000-2004, (Jakarta: Departemen Eksplorasi Laut dan Perikanan RI., 2000), h.3

52 Terumbu karang (coral reefs) merupakan organisme yang hidup di dasar perairan laut dangkal, terutama di daerah tropis. Ia terutama disusun oleh karang-karang jenis anthozoa dari klas Scleractinia yang mana termasuk dalam jenis-jenis karang yang mampu membuat bangunan atau kerangka karang dari kalsium karbonat. Lihat Supriharyono, Pengelolaan Ekosistem Terumbu Karang, (Jakarta: Djambatan, 2000), h. 1, sebagaimana dikutip dari Vaughan, T.W. dan Well, J.W. 1943. "Revision of suborders, families, and genera of the Scleractinia". Pecial Pap. Geology Society American, 44: 1-363

${ }^{53}$ Kasijan Romimohtarto dan Sri Juwana, Biologi Laut ..., h. 437-438

54 Supriharyono, Pengelolaan Ekosistem Terumbu ..., h. VIII

55 Supriharyono, Pengelolaan Ekosistem Terumbu ..., h. 9

${ }^{56}$ Departemen Agama RI., Al Qur'an ..., h. 865

${ }^{57}$ Lihat Mu¥ammad Naw $\pm \mathrm{w}^{3}$ al-J $\pm \mathrm{W}^{3}$, Mar $\pm ¥$..., Juz II, h. 327

${ }^{58} \mathrm{Ab}$ - al- $\mid$ usayn A¥mad ibn F \pm ris ibn Zakariyy \pm , Mu'jam al-Maq \pm yis ..., h. 505

${ }^{99}$ Al-R \pm ghib al $-\mathrm{A}_{i} \mathrm{fah} \pm \mathrm{n}^{3}, M u^{\prime} j a m$ Mufrad $\pm t$..., h. 387

${ }^{60}$ Lihat Mu¥ammad Naw $\pm w^{3}$ al-J $\pm w^{3}$, Mar $\pm ¥$..., Juz II, h. 327

${ }^{61}$ Departemen Eksplorasi Laut dan Perikanan, Program dan Kegiatan ..., h. 3

${ }^{62}$ Departemen Agama RI., Al Qur'an ..., h. 178

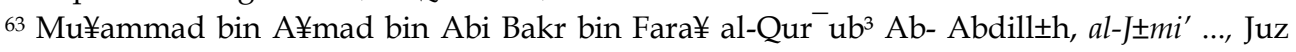
VI, h. 321

${ }^{64}$ Emil Salim, Pembangunan Berwawasan Lingkungan, (Jakarta: LP3ES, 1986), h. 170

65 Otto Soemarwoto, Atur-Diri-Sendiri Paradigma Baru Pengelolaan Lingkungan Hidup, (Yogyakarta: Gadjah Mada University Press, 2001), h. 1-5

${ }^{66}$ Departemen Agama RI., Al Qur'an ..., h. 13

${ }^{67}$ Departemen Agama RI., Al Qur'an ..., h. 816

${ }^{68}$ M. Quraish Shihab, Tafsir al-Mishbah ..., Vol. I, h. 136; dalam kajian Ushul Fiqh, ayat ini dijadikan dasar hukum mubah, dan dari sini lahirlah kaidah ushul : الاصل في الاشياء الاباحة حتي يدل الديل عليل

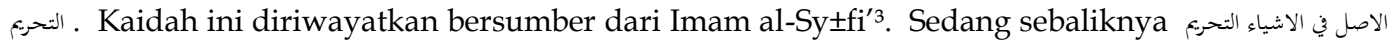
kaidah ini dinisbahkan kepada Imam Ab- | an³fah, walaupun yang terakhir ini dikritik oleh Ibn Nujaim, seorang ulama |anafiyyah, membantah bahwa kaidah ini dari Imam Ab|anifah. Kedua kaidah ini sesungguhnya dapat dikompromikan dengan jalan membedakan tempat berlakunya, yaitu kaidah pertama dalam lapangan muamalah, sedangkan kaidah kedua dalam lapangan ibadah, karena dalam lapangan ibadah, segala perbuatan harus menunggu adanya perintah, sesuai dengan kaidah الاصل في العبادة البطان حتي يقوم دليل على الامر (Hukum pokok tentang ibadah adalah batal (tidak boleh dilakukan hingga ada dalil yang memerintahkan). Lihat Abdul Mudjib, Kaidah-Kaidah Ilmu Figh, al-Qawa'idul Fighiyyah, (Jakarta: Kalam Mulia,1996), h. 26-27 
${ }^{69}$ M. Quraish Shihab, Wawasan Alquran, (Bandung: Mizan, 1996), h. 441

${ }^{70}$ M. Quraish Shihab, Wawasan ..., h. 441-446

${ }^{71}$ Departemen Agama RI., Al Qur'an ..., h. 164

${ }^{72}$ M. Quraish Shihab, Tafsir al-Mishbah ..., Vol. III, h. 83-84

${ }^{73}$ Departemen Agama RI., Al Qur'an ..., h. 164

${ }^{74}$ QS. al-Nist' (4/92 ):1. Pada setiap jiwa manusia terdapat 'tiupan suci' di mana seluruh umat manusia berasal. Maka membunuh seorang manusia, hakikatnya memadamkan 'nyala api suci' yang merupakan asal kehidupan. Lihat 'Abd al-Kar ${ }^{3} \mathrm{~m}$ al-Kha ${ }^{3} \mathrm{~b}$, al-Tafs ${ }^{3} r$ al-Qur' $\pm n^{3}$ li alQur' $\pm n$, (Beirut: D $\pm r$ al-Fikr al-'Arab³, t.th.), Jilid III, h. 1081-1082

75 Penguasaan sumber daya perikanan oleh banyak negara maritim telah menimbulkan kekacauan dalam perikanan moderen, sehingga perlu diciptakan pengaturan antar bangsa berupa konvensi, seperti Konvensi PBB 1982 mengenai Hukum Laut (UNCLOS), khususnya di bidang pemanfaatan sumber daya hayati laut, agar tidak terjadi rebutan. Lihat Kasijan Romimohtarto dan Sri Juwana, op. cit., h. 441. Lebih mendalam mengenai hukum laut internasional, lihat Chairul Anwar, Horizon Baru Hukum Laut Internasional: Konvensi Hukum Laut 1982, (Jakarta: Djambatan, 1989)

76 Statistik aset kewilayahan nasional; jumlah pulau-pulau $=17.508 . \quad$ Dua belas pulau di antaranya merupakan pulau utama, yang masing-masing memiliki luas lebih dari 4.500 kilometer persegi. Luas ke-12 pulau tersebut hampir 97\% dari seluruh luas daratan kepulauan Indonesia. Dari jumlah pulau (17.508) tersebut yang memiliki nama $=5.707$ pulau, yang belum memiliki nama $=11.801$ pulau. Luas perairan Indonesia $=5,9$ juta kilometer persegi. Kepulauan $=2,8$ juta kilometer persegi. Laut teritorial $=0,4$ juta kilometer persegi. Perairan $Z E E=2,7$ kilometer persegi, dan panjang seluruh garis pantai $=80.791$ kilometer. Lihat Tim Penulis PTK BPPT, Profil Kelautan Nasional Menuju Kemandirian, (Bandung: Ilham Jaya, t.th.), h. 13

${ }_{77}$ Saat ini baru beberapa universitas saja yang memiliki fakultas atau jurusan perikanan dan kelautan. Padahal SDM bidang ini masih sangat dibutuhkan untuk mengelola lautan kita yang kaya raya dengan aneka potensi kelautan. Lihat Sahala Hutabarat, "Pemanfaatan Laut Secara Adil Mencegah Disintegrasi Bangsa," Suara Pembaruan, (Jakarta), Kamis, 9 Desember 1999

78 Sahala Hutabarat, Pemanfaatan Lauat Secara Adil ...

${ }^{79}$ Departemen Agama RI., Al Qur'an ..., h. 40

${ }^{80}$ M. Quraish Shihab, Wawasan ..., h. 434

${ }^{81}$ Departemen Agama RI., Al Qur'an ..., h. 1079

${ }^{82}$ Lihat misalnya QS. al-Ra'd (13/96):9

${ }^{83}$ QS. al-Baqarah (2/87):31

${ }^{84} \mathrm{Mu} ¥ \mathrm{ammad} \mathrm{Fu}$ ' \pm ' 'Abd al-B $\pm \mathrm{q}^{3}$, al-Mu'jam al-Mufahras ..., h. 596-611

${ }^{85}$ Al-R \pm ghib al $-\mathrm{A}_{i} \mathrm{fah} \pm \mathrm{n}^{3}$, Mu'jam Mufrad $\pm t$..., h. 356

${ }^{86}$ Departemen Agama RI., Al Qur'an ..., h. 14

${ }^{87}$ M. Quraish Shihab, Wawasan ..., h. 436

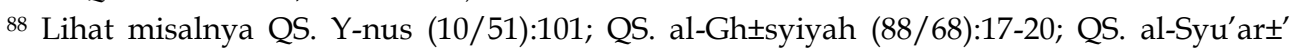
(26/47):7; QS. Y-suf (12/53):109 